\title{
Perbandingan Algoritma Decision Tree C4.5 dan Naive Bayes pada Analisis Tekstur Gray Level Co-occurrence Matrix Menggunakan Citra Wajah
}

\author{
${ }^{1}$ Hamdun Sulaiman*, ${ }^{2}$ Dwiza Riana, ${ }^{3}$ Achmad Rifai \\ ${ }^{1}$ Sistem Informasi, Fakultas Teknik dan Informatika, Universitas Bina Sarana Informatika \\ Jl. Kramat Raya No. 98 Jakarta Pusat, Indonesia \\ ${ }^{2}$ Ilmu Komputer, STMIK Nusa Mandiri \\ ${ }^{3}$ Teknik Informatika, STMIK Nusa Mandiri \\ ${ }^{2,3}$ Nusa Mandiri Tower Jatiwaringin, No 2, Cipinang Melayu, Makasar, jakarta Timur, 13620, \\ Indonesia \\ *e-mail: hamdun.hsl@bsi.ac.id
}

(received: 23 Februari 2021, revised: 12 April 2021, accepted: 6 Mei 2021)

\begin{abstract}
Abstrak
Analisis tekstur lazim dimanfaatkan sebagai proses untuk melakukan klasifikasi dan interpretasi citra. Suatu proses klasifikasi citra berbasis analisis tekstur pada umumnya membutuhkan tahapan ekstraksi ciri, yang terdiri dari tiga macam metode yaitu metode statistik, metode spaktral dan metode struktural. Metode GLCM (Gray-Level Co-Occurrence Matrix) termasuk dalam metode statistik di mana dalam perhitungan statistiknya menggunakan distribusi derajat keabuan dengan mengukur tingkat kekontrasan, granularitas (ukuran), dan kekasaran suatu daerah dari hubungan ketetanggaan antar piksel di dalam citra. Tujuan penelitian ini mencari nilai akurasi yang baik dengan membandingkan algoritma decision tree $\mathrm{C} 4.5$ dan naive bayes pada analisis tekstur Gray Level Cooccurrence Matrix (GLCM) menggunakan citra wajah. Tools yang digunakan untuk ektrasi fitur menggunakan MATLAB dan untuk klasifikasi algoritmanya menggunakan tools Rapid miner. Dari hasil penelitian untuk nilai terbaik pada perbandingan algoritma dengan analisis tekstur Gray-Level Co-Occurrence Matrix (GLCM) menggunakan citra wajah. Untuk nilai akurasi terhadap 2 kelas dengan algoritma klasifikasi C4.5 sebesar 58,64\%, sedangkan untuk nilai akurasi algoritma klasifikasi Naive Bayes sebesar $75,45 \%$ sedangkan untuk nilai akurasi terhadap 3 kelas dengan algoritma klasifikasi C4.5 sebesar 54,74\%\%, sedangkan untuk nilai akurasi algoritma klasifikasi Naive Bayes sebesar 62,63\%. Dapat disimpukan bahwa algoritma Naive Bayes memiliki nilai terbaik dalam analisis tekstur Gray-Level Co-Occurrence Matrix (GLCM) menggunakan citra wajah baik terhadap 2 kelas maupun yang 3 kelas.
\end{abstract}

Kata kunci: analisis tekstur, citra wajah, gray level co-occurrence matrix, algoritma $c 4.5$, algoritma klasifikasi naive bayes

\begin{abstract}
Texture analysis is commonly used as a process for image classification and interpretation. An image classification process based on texture analysis generally requires feature extraction stages, which consist of three types of methods namely statistical methods, spactral methods and structural methods. The GLCM (Gray-Level Co-Occurrence Matrix) method is included in the statistical method in which statistical calculations use gray level distribution by measuring the contrast level, granularity (size), and roughness of an area from the neighboring relationships between pixels in the image. The purpose of this study is to find a good value of accuracy by comparing the C4.5 decision tree and naive bayes on the Gray Level Co-occurrence Matrix (GLCM) texture analysis using face images. The tools used for feature extraction use MATLAB and for the classification of the algorithm use Rapid Miner tools. From the results of the study for the best value in the comparison of algorithms with Gray-Level Co-Occurrence Matrix (GLCM) texture analysis using face images. For the accuracy of the two classes with C4.5 classification algorithm is 58.64\%, while for the Naive Bayes classification algorithm accuracy value is $75.45 \%$ while for the accuracy of the 3 classes with C4.5 classification
\end{abstract}


algorithm is $54.74 \% \%$, while for the Naive Bayes classification algorithm accuracy value is $62.63 \%$. It can be concluded that the Naive Bayes algorithm has the best value in Gray-Level Co-Occurrence Matrix (GLCM) texture analysis using face images for both classes and 3 classes.

Keywords: texture analysis, facial image, gray level co-occurrence matrix, c4.5 algorithm, naive bayes classification algorithm.

\section{Pendahuluan}

Analisis tekstur lazim dimanfaatkan sebagai proses untuk melakukan klasifikasi dan interpretasi citra. Suatu proses klasifikasi citra berbasis analisis tekstur pada umumnya membutuhkan tahapan ekstraksi ciri, yang terdiri dari tiga macam metode yaitu metode statistik, metode spaktral dan metode struktural. Metode GLCM (Gray-Level Co-Occurrence Matrix) termasuk dalam metode statistik di mana dalam perhitungan statistiknya menggunakan distribusi derajat keabuan dengan mengukur tingkat kekontrasan, granularitas (ukuran), dan kekasaran suatu daerah dari hubungan ketetanggaan antar piksel di dalam citra (Syifa et al., 2016).

Ekstraksi ciri dengan analisis tekstur dilakukan dengan mengambil ciri dari citra grayscale untuk membedakan obyek satu dengan obyek lainnya. Pada analisis tekstur secara statistis, fitur tekstur dihitung berdasarkan distribusi statistik dari kombinasi intensitas piksel pada posisi tertentu relatif terhadap lainnya dalam suatu matriks citra. Ekstraksi fitur merupakan langkah awal dalam melakukan klasifikasi dan interpretasi citra. Proses ini berkaitan dengan kuantisasi karakteristik citra ke dalam sekelompok nilai ciri yang sesuai (Sofie \& Rizal, 2016).

Gray Level Co-occurrance Matrix (GLCM) dikembangkan oleh Haralick et al (1973), adalah metodologi pemrosesan gambar yang digunakan untuk menggambarkan hubungan spasial antara nilai-nilai abu-abu dalam gambar 2 dimensi. Karya asli Haralick et al. (1973) melangkah lebih jauh untuk menunjukkan tingkat penerapannya pada photomicrographs level abu-abu dari serangkaian sampel batu pasir. Sejak itu, GLCM telah digunakan secara luas dalam berbagai aplikasi. Dari semua teknik analisis tekstur, saat ini mungkin yang paling banyak digunakan adalah yang didasarkan pada algoritma $G L C M$. Sebagai cara untuk mengklasifikasikan gambar menggunakan pengukuran statistik urutan kedua (Kurniawan \& Riana, 2018).

Dalam penelitian ini akan membandingkan algoritma decision tree C4.5 dan naive bayes pada analisis tekstur GLCM menggunakan citra wajah, yang nantinya algoritma mana yang cocok atau yang mempunyai nilai akurasi terbaik untuk analisis tekstur GLCM dengan membandingkan kedua algoritma tersebut.

\section{Tinjauan Literatur}

Penelitian yang dilakukan (Santoni et al., 2015) yang berjudul Cattle Race Classification Using Gray Level Co-occurrence Matrix Convolutional Neural Networks, Penelitian ini memodifikasi CNN menggunakan fitur GLCM. Modifikasi pada layer input dengan gambar GLCM dapat meningkatkan akurasi identifikasi ras sapi, dibandingkan dengan CNN itu sendiri. Titik kuat dari modifikasi adalah data informasi dalam lapisan input memiliki fitur yang lebih baik menggunakan fitur GLCM daripada gambar aslinya. Dalam metode ini, tidak memerlukan proses segmentasi untuk klasifikasi ras sapi dan menggunakan tiga sifat fitur GLCM, ada kontras, energi dan homogenitas. Citra kontras dan energi dapat meningkatkan akurasi CNN, tetapi berbanding terbalik dengan citra homogenitas, yang memiliki akurasi lebih rendah. GLCM-CNN dapat meningkatkan akurasi CNN dengan iterasi kecil. Setelah 50 iterasi, CNN memiliki akurasi $76.773 \%$, sedangkan GLCM-CNN menggunakan gambar kontras dapat memperoleh akurasi $89.677 \%$, di mana akurasi ini diperoleh oleh CNN menggunakan 100 iterasi. Akurasi tertinggi diperoleh oleh GLCM-CNN menggunakan gambar energi dengan akurasi 93.763\% untuk 100 iterasi. Penelitian yang dilakukan oleh (Vijayarani \& Priyatharsini, 2015) yang berjudul Facial Feature Extraction Based On FPD and GLCM Algorithms, pada penelitian ini menganalisis kinerja dua algoritma ekstraksi fitur wajah dengan membandingkan Face Part Detection (FPD) dan Gray Level Co-occurrence Matrix (GLCM), terbukti bahwa fitur ekstrak GLCM akurat. FPD menggunakan lima belas gambar dan semua gambar lima belas memiliki fitur yang diekstrak sebagai mata, alis dan bibir. Di sini hanya kotak pembatas yang mewakili fitur tetapi tidak mengekstrak secara terpisah untuk semua gambar. GLCM menggunakan semua gambar lima belas, 
dan ekstrak fitur secara terpisah sebagai mata, alis dan bibir. Teknik moment affine invariant dilakukan dan menggunakan fitur diekstrak secara mutlak dan benar untuk semua gambar. Hal ini jelas menunjukkan bahwa GLCM mendeteksi fitur dengan benar daripada algoritma FPD. Akurasi yang diperoleh algoritma FPD sebesar 78\% sedangkan algoritma GLCM sebesar 90\%. Dari ukuran akurasi terbukti bahwa algoritma GLCM bekerja lebih baik daripada algoritma FPD dengan nilai akurasi tertinggi dengan menggunakan SVM (Support vector machine). SVM dilakukan untuk melatih dan menguji gambar dan menemukan keakuratannya. Dengan melatih dan menguji gambar, ditemukan nilai akurasi tertinggi dengan mengekstraksi fitur secara akurat berdasarkan parameter SVM. Penelitian yang dilakukan oleh (Hayatin, 2016) yang berjudul Klasifikasi Kelompok Usia Berdasarkan Citra Wajah Menggunakan Algoritma Neural Network Dengan Fitur Face Anthropometry Dan Kedalam Kerutan. Dalam Penelitian ini Penelitian ini telah mampu melakukan pengelompokan usia berdasarkan citra wajah menggunakan face anthropometry dengan memperhitungkan lebar dan kedalaman kerutan. Dimana untuk ekstraksi kerutan wajah digunakan gabungan operator Sobel dan histogram equalization. Metode yang digunakan untuk pengelompokan usia dibedakan menjadi 4 tahapan yaitu: Praproses, identifikasi lokasi titik wajah, ekstraksi fitur dan klasifikasi. Dengan menggunakan algoritma NN, metode yang diusulkan telah mampu mengelompokan usia dengan cukup baik kedalam 3 kelas yaitu anak, remaja dan tua dengan hasil akurasi pengujian sebesar $65 \%$

\section{Metode Penelitian}

Jenis penelitian yang dilakukan pada penelitian ini adalah jenis penelitian eksperimen. Metode ini menguji kebenaran sebuah hipotesis dengan statistik dan menghubungkannya dengan masalah penelitian (Kothari, 2004). Jenis penelitian eksperimen dibagi dua, yaitu eksprimen absolut dan eksperimen komparatif. Eksperimen absolut mengarah kepada dampak yang dihasilkan dari eksperimen. Sedangkan eksperimen komparatif yaitu membandingkan dua objek yang berbeda, misalnya membandingkan dua algoritma yang berbeda dengan melihat hasil statistik masing-masing mana yang lebih baik (Kothari, 2004).

Tujuan dari penelitian ini adalah melakukan perbandngan algoran klasifikasi decision tree (C4.5) dan naive bayes pada metode analisis tekstur Gray-Level Co-Occurrence Matrix (GLCM) dengan menggunakan citra wajah, untuk mengetahui algoritma yang memiliki nilai akurasi yang baik dalam mengolah hasil ektrasi citra.

Metode pengumpulan data dibagi menjadi dua sumber data yaitu data primer dan data sekunder. Data primer yaitu data yang dikumpulkan pertama kali, dan untuk melihat apa yang sesungguhnya terjadi melalui observasi, interview, kuesioner. Data sekunder adalah data yang telah dikumpulkan dan dianalisis oleh orang lain baik yang telah dipublikasikan maupun yang belum dipublikasikan, misalnya dari dokumentasi, literatur, buku, jurnal dan informasi lainnya yang ada hubungannya dengan masalah yang diteliti.

Dalam penelitian ini metode pengumpulan data untuk mendapatkan sumber data yang digunakan adalah metode pengumpulan data sekunder. Data utama citra wajah dari database KinFaceW yang dapat diperoleh melalui alamat web http://www.kinfacew.com/download.html sedangkan data pendukung didapatkan dari buku, jurnal dan publikasi lainnya.

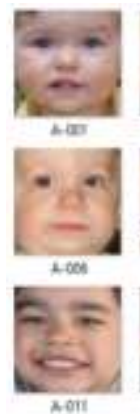

a.tin

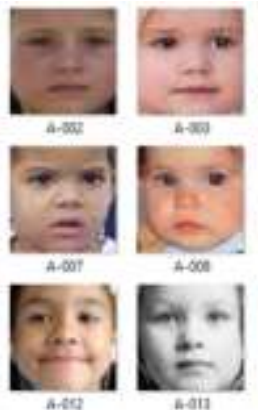

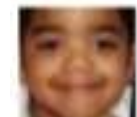
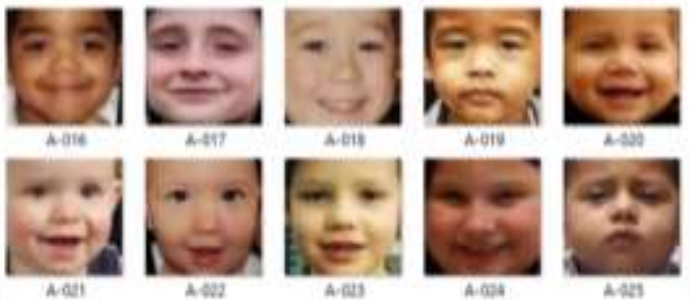

Gambar 1. Sampel Citra Wajah Anak 

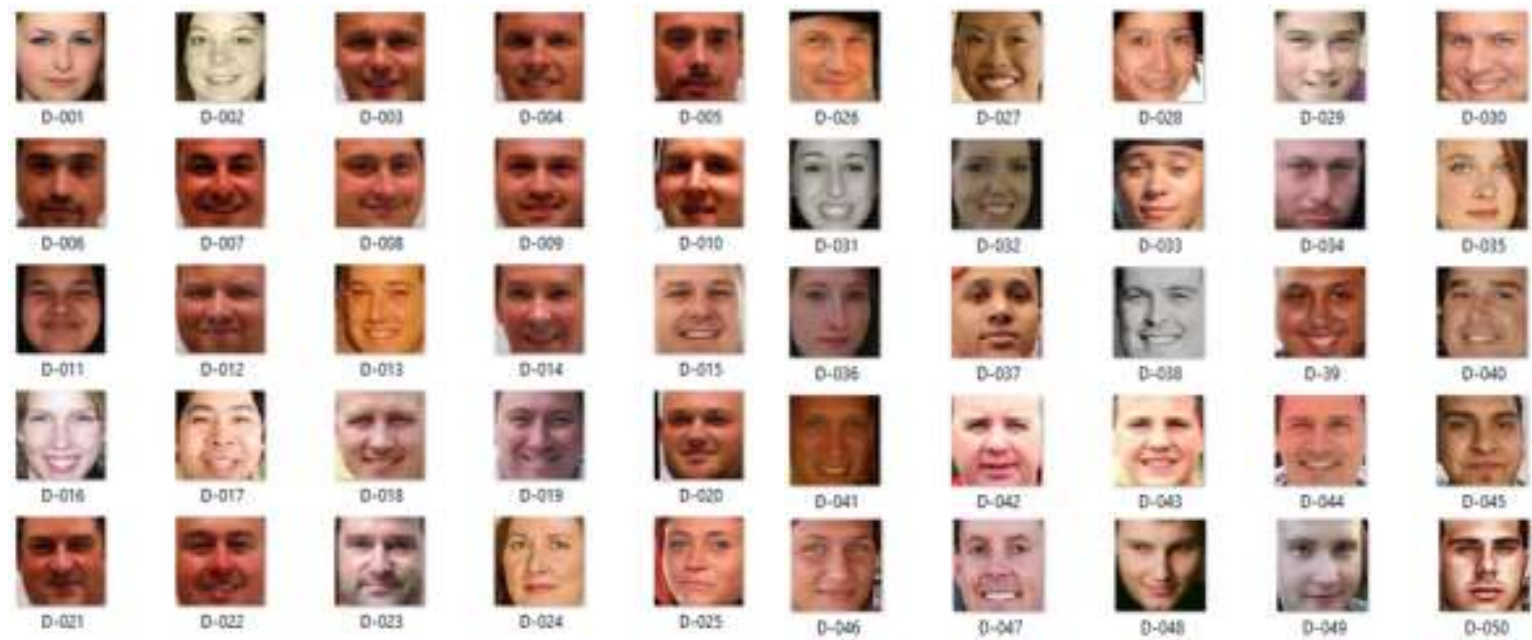

Gambar 2. Sampel Citra Wajah Dewasa
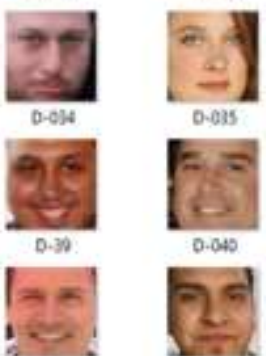

0.045
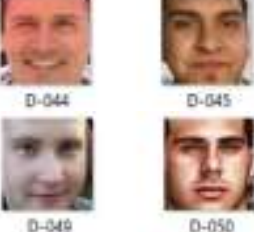

$0-30$

$0-050$
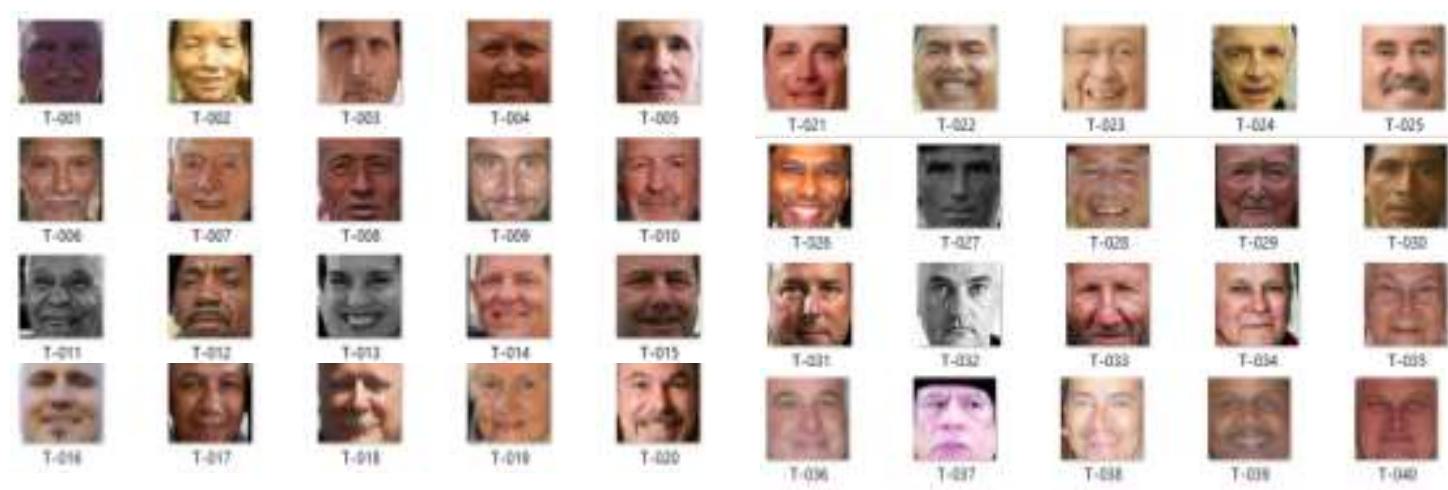

Gambar 3. Sampel Citra Wajah Tua

Tabel 1. Jumlah Data 2 Kelas

\begin{tabular}{ccc}
\hline Citra & Kelas & Jumlah Citra \\
\hline D-026-D-115 & Dewasa & 90 \\
T-016- T-145 & Tua & 130. \\
& & \\
\hline
\end{tabular}

Tabel 2. Jumlah Data 3 Kelas

\begin{tabular}{ccc}
\hline Citra & Kelas & Jumlah Citra \\
\hline A-001-A-050 & Anak & 50 \\
D-001 - D-048 & Dewasa & 48 \\
T-001 - T-092 & Tua & 92 \\
\hline
\end{tabular}

Penelitian ini akan membandingkan algoritma decision tree C4.5 dan Naive Bayes untuk mencari mana algoritma yang terbaik pada analisis tekstur Gray-Level Co-Occurrence Matrix (GLCM) menggunakan citra wajah.

Pengujian terhadap metode yang akan digunakan, membutuhkan desain penelitian yang jelas dan tepat. Desain yang akan dibuat akan digunakan sebagai tahapan proses pengujian untuk mendapatkan hasil yang diinginkan. Maka dari itu pada Gambar 1 menjelaskan sebuah model desain penelitian yang dilakukan. 


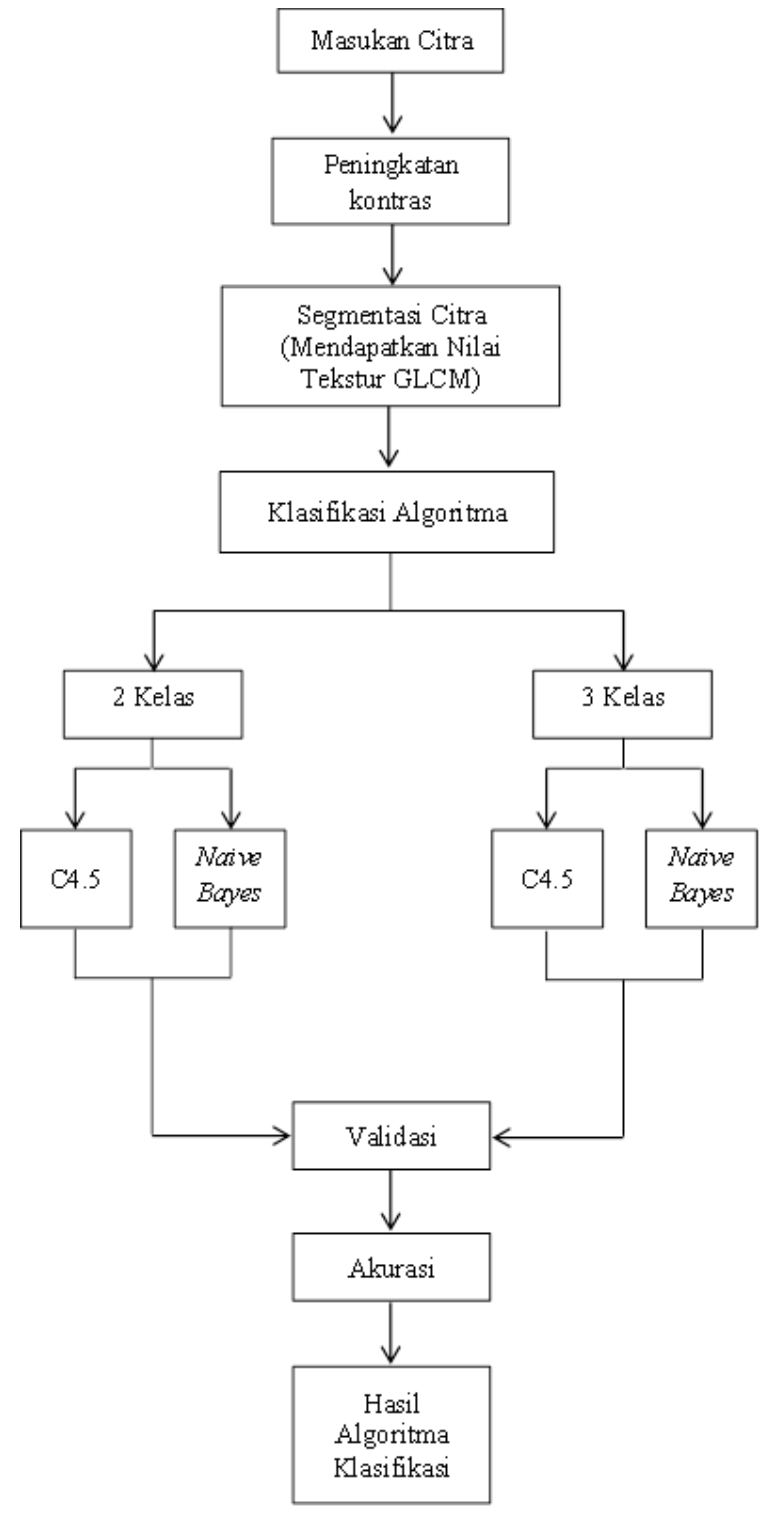

\section{Gambar 4. Model Desain Penelitian}

Dari kerangka model penelitian yang diusulkan pada Gambar 4. Model Desain Penelitian dapat dijelaskan sebagai berikut:

1. Menyiapkan database citra wajah

2. Masukan citra

3. Melakuakan peningkatan kintras Preprocessing

4. Melakukan segmentasi cintra untuk mendapatkan nilai tekstur GLCM

5. Melakukan training dan testing untuk 2 kelas terhadap model C4.5 dan Naiv Bayes dan mencatat hasil Accuracy.

6. Melakukan training dan testing untuk 3 kelas terhadap model C4.5 dan Naiv Bayes dan mencatat hasil Accuracy.

7. Menilai model yang menghasilkan nilai Accuracy yang baik.

\section{Hasil dan Pembahasan}

\subsection{Ektrasi Fitur Citra Wajah}

Di bawah ini merupakan hasil ektrasi fitur citra wajah yang di implementasikan dengan analisis tekstur Gray-Level Co-Occurrence Matrix (GLCM) ke dalam GUI MATLAB. Pertama masukan citra wajah yang akan di analisis, kemudian meningkatkan kontrasnya, selanjutnya di segmentasi citra yang 
dimasukan, yang nantinya akan ada classtering untuk memilih hasil segmentasi dalam analisis tekstur pada citra wajah dan akhirnya akan menghasilkan nilai parameter dari analisis tekstur tersebut.

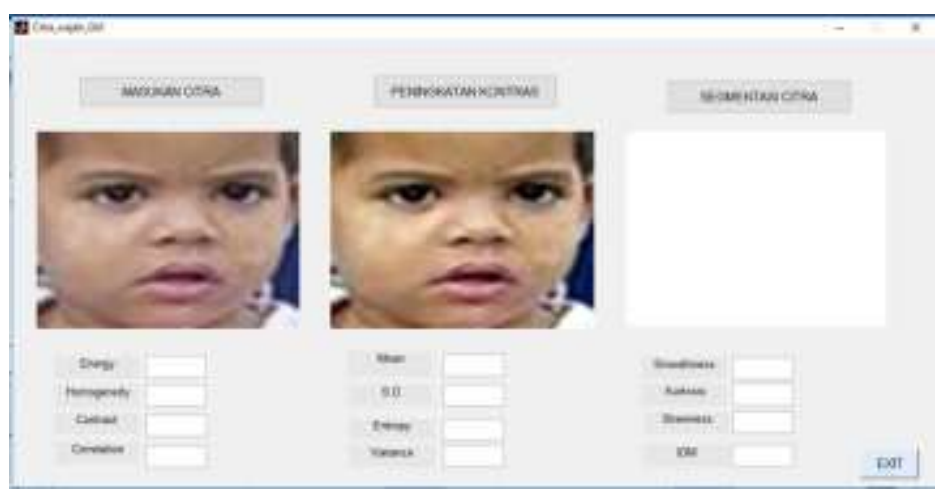

\section{Gambar 5. Masukan Cintra dan Peningkatan Kontras}

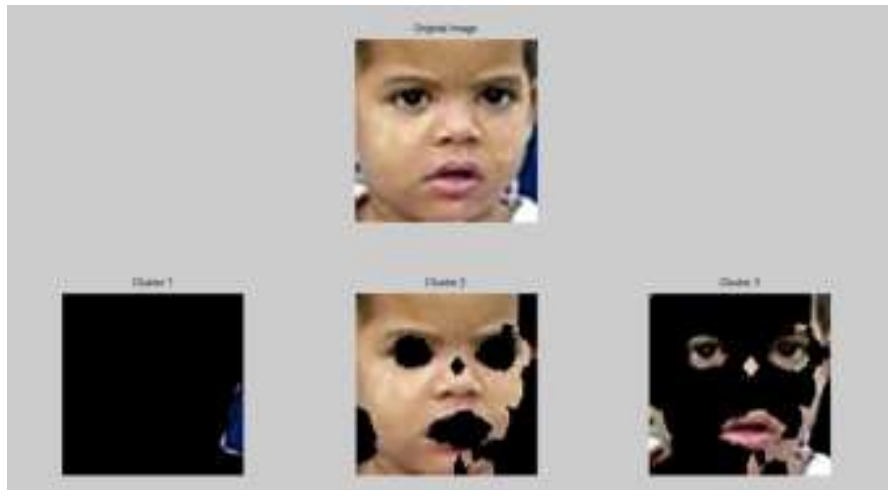

Gambar 6. Clusstering Segmentasi Citra

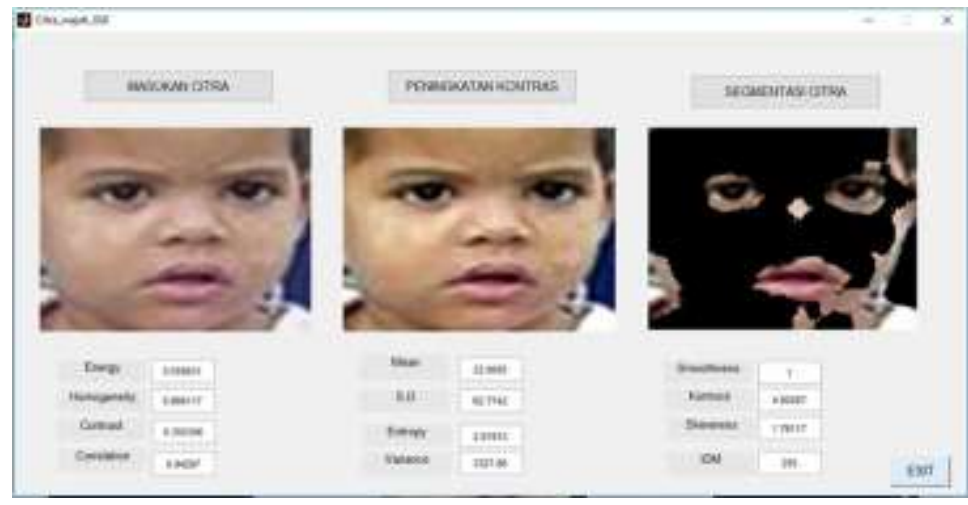

Gambar 7. Hasil Segmentasi Citra

\subsection{Pengujian Algoritma}

Pengujian Algoritma bertujuan membandingkan algoritma Decision Tree (C4.5) dan algortima Naive Bayes pada nilai teksur GLCM dengan citra wajah. Yang nantinya algoritma mana yang memiliki nilai akurasi terbaik.

1. Hasil Pengujian algoritma C4.5

a. Evaluasi dengan Cofusion Matrix 2 Kelas 
Model confusion matrix akan menghasilkan matrix yang terdiri dari true fositif atau true negative setelah data testing di masukan kedalam model confusion metrix hasilnya akan terlihat seperti gambar dibawah:

\begin{tabular}{|c|c|c|c|}
\hline \multicolumn{4}{|c|}{ accuracy. $58.64 \%+{ }^{\square}+1.36^{\%}$ (mikro: $58.64 \%$ ) } \\
\hline & true Dewasa & true tua & class precision \\
\hline pred. Dewasa & 0 & 1 & $0.00 \%$ \\
\hline pred. tua & 90 & 129 & $58.90 \%$ \\
\hline class recall & $0.00 \%$ & $99.23 \%$ & \\
\hline
\end{tabular}

\section{Gambar 8. Confusion Matrix Algoritma C4.5 Untuk 2 Kelas}

Berdasarkan Gambar 8. dari 220 set data, bahwa algoritma C4.5 dapat memprediksi kelas dewasa sebanyak 0 dan 1 kelas dewasa dianggap tua. Kelas tua dapat diprediksi sebanyak 129 dan 90 kelas tua dianggap dewasa. Sehingga didapatkan class precision atau sensitivity untuk memprediksi kelas dewasa sebesar $0,00 \%$ dan untuk kelas tua atau specifity sebesar $58,90 \%$. Class recall untuk true dewasa atau $P P V$ sebesar $0,00 \%$ dan true tua atau NPV sebesar 99,23\%.

Dari data tersebut maka dapat dihitung nilai accuracy dengan menggunakan persaman.

Accuracy $=\frac{\mathrm{TP}+\mathrm{TN}}{\mathrm{TP}+\mathrm{TN}+\mathrm{FP}+\mathrm{FN}}$
Accuracy $=\frac{0+129}{0+129+90+1}=0,58636(58,64 \%)$

b. Evaluasi dengan Cofusion Matrix 3 Kelas

Model confusion matrix akan menghasilkan matrix yang terdiri dari true fositif atau true negative setelah data testing di masukan kedalam model confusion metrix hasilnya akan terlihat seperti gambar dibawah:

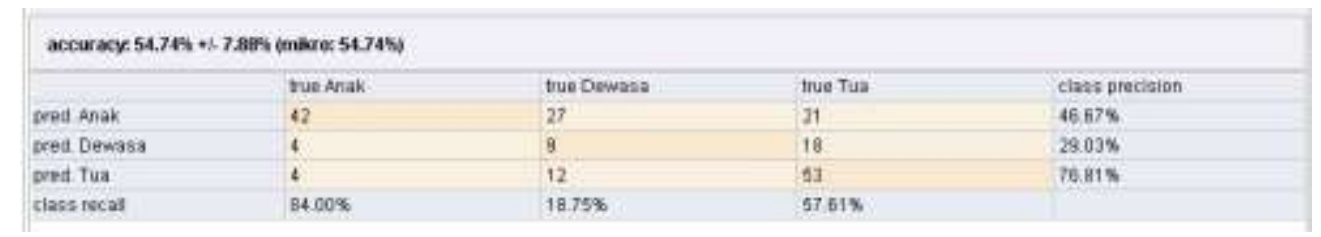

Gambar 9. Confusion Matrix Algoritma C4.5 Untuk 3 Kelas

Berdasarkan Gambar 9. dari 190 set data, bahwa algoritma C4.5 dapat memprediksi kelas anak sebanyak 42 , kelas anak dianggap dewasa 27 kelas dan kelas anak dianggap tua 21. Kelas dewasa dapat diperidiksi sebanyak 9, 18 dianggap tua dan 4 kelas dianggap anak. Kelas tua dapat diprediksi sebanyak 53, 12 dianggap dewasa dan 4 dianggap anak. Sehingga didapatkan class precision atau sensitivity untuk memprediksi kelas anak sebesar 46,67\%, untuk dewasa sebesar $29,03 \%$ dan untuk kelas tua atau specifity sebesar $76,81 \%$. Class recall untuk true anak atau $P P V$ sebesar $84,00 \%$, true dewasa 18,75 dan true tua atau NPV sebesar 57,61\%.

Dari data tersebut maka dapat dihitung nilai accuracy dengan menggunakan persaman.

Accuracy $=\frac{\mathrm{TP}+\mathrm{TN}}{\mathrm{TP}+\mathrm{TN}+\mathrm{FP}+\mathrm{FN}}$
Accuracy $=\frac{42+9+53}{42+9+53+27+21+4+18+4+12}=0,54736(54,74 \%)$

2. Hasil Pengujian algoritma Naive Bayes

a. Evaluasi dengan Cofusion Matrix 2 Kelas

Model confusion matrix akan menghasilkan matrix yang terdiri dari true fositif atau true negative setelah data testing di masukan kedalam model confusion metrix hasilnya akan terlihat seperti gambar dibawah: 


\begin{tabular}{|c|c|c|c|}
\hline \multicolumn{4}{|c|}{ accuracy: $75.45^{\%}+/-8.91 \%$ (mikro: $75.45^{\%}$ ) } \\
\hline & true Dewasa & true tua & class precision \\
\hline pred. Dewasa & 38 & 2 & $95.00 \%$ \\
\hline pred. tua & 52 & 128 & $71.11 \%$ \\
\hline class recall & $42.22 \%$ & $98.46 \%$ & \\
\hline
\end{tabular}

Gambar 10. Confusion Matrix Algoritma Naive Bayes Untuk 2 Kelas

Berdasarkan Gambar 4.6. dari 220 set data, bahwa algoritma naive bayes dapat memprediksi kelas dewasa sebanyak 38 dan 2 kelas dewasa dianggap tua. Kelas tua dapat diprediksi sebanyak 128 dan 52 kelas tua dianggap dewasa. Sehingga didapatkan class precision atau sensitivity untuk memprediksi kelas dewasa sebesar $95,00 \%$ dan untuk kelas tua atau specifity sebesar $71,11 \%$. Class recall untuk true dewasa atau $P P V$ sebesar $42,22 \%$ dan true tua atau NPV sebesar 98,46\%.

Dari data tersebut maka dapat dihitung nilai accuracy dengan menggunakan persaman.

Accuracy $=\frac{\mathrm{TP}+\mathrm{TN}}{\mathrm{TP}+\mathrm{TN}+\mathrm{FP}+\mathrm{FN}}$
Accuracy $=\frac{38+128}{38+128+52+2}=0,7545(75,45 \%)$

b. Evaluasi dengan Cofusion Matrix 3 Kelas

Model confusion matrix akan menghasilkan matrix yang terdiri dari true fositif atau true negative setelah data testing di masukan kedalam model confusion metrix hasilnya akan terlihat seperti gambar dibawah:

\begin{tabular}{|c|c|c|c|c|}
\hline \multicolumn{5}{|c|}{ 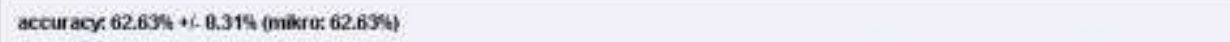 } \\
\hline & rue anak & tue Derwasa & twe Tua & ciass precision \\
\hline prec Anak & 43 & 14 & 2. & 72804 \\
\hline pred. Denasa & 5 & 2 & 16 & $8.70 \mathrm{x}$ \\
\hline pred. Tus & 2 & 32 & 74 & $68.52 \%$ \\
\hline class recal & $86.00 \%$ & $4.17 \%$ & $8043 \%$ & \\
\hline
\end{tabular}

Gambar 11. Confusion Matrix Algoritma Naive Bayes Untuk 3 Kelas

Berdasarkan Gambar 4.7. dari 190 set data, bahwa algoritma naive bayes dapat memprediksi kelas anak sebanyak 43 , kelas anak dianggap dewasa 14 kelas dan kelas anak dianggap tua 2. Kelas dewasa dapat diperidiksi sebanyak 2, 16 dianggap tua dan 5 kelas dianggap anak. Kelas tua dapat diprediksi sebanyak 74, 32 dianggap dewasa dan 2 dianggap anak. Sehingga didapatkan class precision atau sensitivity untuk memprediksi kelas anak sebesar $72,88 \%$, untuk dewasa sebesar $8,70 \%$ dan untuk kelas tua atau specifity sebesar $68,52 \%$. Class recall untuk true anak atau $P P V$ sebesar $86,00 \%$, true dewasa 4,17 dan true tua atau NPV sebesar $80,43 \%$.

Dari data tersebut maka dapat dihitung nilai accuracy dengan menggunakan persaman.

Accuracy $=\frac{\mathrm{TP}+\mathrm{TN}}{\mathrm{TP}+\mathrm{TN}+\mathrm{FP}+\mathrm{FN}}$
Accuracy $=\frac{43+2+74}{43+2+74+14+2+5+16+2+32}=0,6263(62,63 \%)$

\subsection{Hasil Perbandingan Algoritma}

Dari hasil pengujian yang telah dilakuan, dihasilkan nilai perbandingan algoritma decision tree dan algoritma naive bayes pada nilai analisis tekstur GLCM dengan menggunakan citra wajah bahwa: 
Tabel 3. Hasil Perbandingan Algoritma

\begin{tabular}{ccc}
\hline Kelas & $\begin{array}{c}\text { Algoritma Decision Tree } \\
(\text { C4.5) }\end{array}$ & Algoritma Naive Bayes \\
\hline 2 Kelas & $58,64 \%$ & $75,45 \%$ \\
3 Kelas & $54,74 \%$ & $62,63 \%$ \\
\hline
\end{tabular}

\section{Kesimpulan}

Dari hasil penelitian untuk nilai terbaik pada perbandingan algoritma dengan analisis tekstur Gray-Level Co-Occurrence Matrix (GLCM) menggunakan citra wajah. Untuk nilai akurasi terhadap 2 kelas dengan algoritma klasifikasi C4.5 sebesar 58,64\%, sedangkan untuk nilai akurasi algoritma klasifikasi Naive Bayes sebesar 75,45\% sedangkan untuk nilai akurasi terhadap 3 kelas dengan algoritma klasifikasi C4.5 sebesar 54,74\%\%, sedangkan untuk nilai akurasi algoritma klasifikasi Naive Bayes sebesar 62,63\%.

Dapat disimpukan bahwa algoritma Naive Bayes memiliki nilai terbaik dalam analisis tekstur Gray-Level Co-Occurrence Matrix (GLCM) menggunakan citra wajah baik terhadap 2 kelas maupun yang 3 kelas.

\section{Referensi}

[1] Ardiyansyah, Rahayuningsih, P. A., \& Maulana, R. (2018, Juni). Analisis Perbandingan Algoritma Klasifikasi Data Mining Untuk Dataset Blogger Dengan Rapid Miner. Jurnal Khatulistiwa Informatika, VOL. VI(p-ISSN: 2339-1928 \& e-ISSN: 2579-633X), 20-28.

[2] Buani, D. P. (2016). Optimasi Algoritma Naïve Bayes dengan Menggunakan Algoritma Genetika untuk Prediksi Kesuburan (Fertility). Jurnal Evolusi , Volume 4 Nomor 1(ISSN : 2338 - 8161), 54-63.

[3] Dewi, R. K., \& Ginardi, R. H. (2014). IDENTIFIKASI PENYAKIT PADA DAUN TEBU DENGAN GRAY LEVEL COOCCURRENCE MATRIX DAN COLOR MOMENTS. Jurnal Teknologi Informasi dan Ilmu Komputer, Vol. 1, No. 2.

[4] Dawson, C. W. (2009). Projects in Computing and Information Systems a student's guide. Harlow, UK: Addison-Wesley.

[5] Gujral, E. R., \& Nishi, E. (2015). A Novel technique for the Detection of Mixed Noise in Medical Images using Datamining. Vol.8, No.11 231-242.

[6] Hayatin, N. (2016). Klasifikasi kelompok usia berdasarkan citra wajah menggunakan algoritma neural network dengan fitur face anthropometry dan kedalam kerutan. 61-67.

[7] Kurniawan, I., \& Riana, D. (2018). Analisa Tekstur Kulit Wajah Menggunakan Fitur Gray Level Co-Occurrance Matrix. Seminar Nasional Inovasi dan Tren (SNIT), 187-192.

[8] Latif,M.H, A., Yusof,H, M., Sidek,S.N, \& Rusli, N. (2015). Implementation Of GLCM Features In Thermal Imaging For Human Affective State Detection. IRIS, 308-315.

[9] Li, R., Liu, P., Jia, K., \& Wu, Q. (2015). Facial Expression Recognition under Partial Occlusion Based on Gabor Filter and Gray-level Co-occurrence Matrix.

[10] Maurya, R., Singh, S. K., Maurya, A. K., \& Kumar, A. (2014). GLCM and Multi Class Support Vector Machine based Automated Skin Cancer Classification.

[11] Markkongkeaw, A., Phinyomark, A., Boonyapipha, P., \& Phukpattaranont, P. (2013). Preliminary Results of Breast Cancer Cell Classifying Based on Gray-Level Co-occurrence Matrix. BMEiCON.

[12] Mishra, S., Majhi, B., Sa, P. K., \& Sharma, L. (2017). Gray level co-occurrence matrix and random forest based acute lymphoblastic leukemia detection. 272-280.

[13] Mukminin, A., \& Riana, D. (2017). Komparasi Algoritma C4.5, Naïve Bayes Dan Neural Network Untuk Klasifikasi Tanah. JURNAL INFORMATIKA, Vol.4 No.1, 21-31.

[14] Nugroho, D., Nhita, F., \& Trantoro, D. (Agustus 2016). Prediksi Penyakit Menggunakan Genetic Algorithm (GA) dan Naive Bayes Untuk Data Berdimensi Tinggi. e-Proceeding of Engineering, Vol.3, No.2, hal. 3889-3899. 
[15] Permadi, Y., \& Murinto. ( 2015). APLIKASI PENGOLAHAN CITRA UNTUK IDENTIFIKASI KEMATANGAN MENTIMUN BERDASARKAN TEKSTUR KULIT BUAH MENGGUNAKAN METODE EKSTRAKSI CIRI STATISTIK. JURNAL INFORMATIKA Vol. 9, No. 1, 1028-1038.

[16] Permata, E. (2016). IDENTIFIKASI OBYEK BENDA TAJAM MENGGUNAKAN PENGOLAHAN CITRA DIGITAL PADA CITRA X-RAY. VOLT Vol. 1, No. 1.

[17] Pramunendar, R. A., Supriyanto, C., Novianto, D. H., Yuwono, I. N., Shidik, G. F., \& Andono, P. N. (2013). A Classification Method of Coconut Wood Quality Based on Gray. ROBIONETICS.

[18] Prasetyo, E. (2011). Pengolahan citra digital dan aplikasinya menggunakan Matlab. Yogyakarta: Penerbit Andi.

[19] Pratiwi, M., Alexander, Harefa, J., \& Nanda, S. (2015). Mammograms Classification using Graylevel Co-occurrence Matrix and Radial Basis Function Neural Network. ICCSCI , 83-91.

[20] Ramanda, K. (2015, Agustus). Penerapan Particle Swarm Optimization Sebagai Seleksi Fitur Prediksi Kelahiran Prematur Pada Algoritma Neural Network. Jurnal Teknik Komputer AMIK BSI, VOL. I NO. 2 (ISSN. 2442-2436), 178-183.

[21] osandy, T. (2016, Mei). Perbandingan Metode Naive Bayes Classifier dengan Metode Decison Tree (C4.5) Untuk Menganalisa Kelancaran Pembiayaan (Study Kasus: KSPPS/BMT AlFadhila). Jurnal TIM Darmajaya, Vol. 02 No. 01(ISSN: 2442-5567 | E-ISSN: 2443-289X), 5262.

[22] Qayyum, R., Kamal, K., Zafar, T., \& Mathavan, S. (2016). Wood Defects Classification Using GLCM Based Features And PSO Trained Neural Network.

[23] S, A. B., Suma'inna, \& Maulana, H. (2016). Pengenalan Citra Wajah Sebagai Identifier Menggunakan Metode Principal Component Analysis (PCA). JURNAL TEKNIK INFORMATIKA, VOL 9 NO. 2.

[24] Santoni, M. M., Sensuse, D. I., Arymurthy, A. M., \& Fanany, M. I. (2015). Cattle Race Classification Using Gray Level Co-occurrence Matrix Convolutional Neural Networks. ICCSCI, $493-502$.

[25] Saputra, R. A. (2014). Komparasi Algoritma Klasifikasi Data Mining Untuk Memprediksi Penyakit Tuberculosis (TB): Studi Kasus Puskesmas Karawang Sukabumi. Seminar Nasional Inovasi dan Tren (SNIT), (hal. 1-8). Sukabumi.

[26] Sugiyono. (2013). Metode Penelitian Kuantitatif Kualitatif dan R\&D. Bandung: Alfabeta.

[27] Sofie, M., \& Rizal, A. (2016). KLASIFIKASI CITRA REKAMAN SINYAL ELEKTROKARDIOGRAM MENGGUNAKAN METODE ANALISIS TEKSTUR, K-NN DAN MULTILAYER PERCEPTRON. Jurnal SIMETRIS, Vol 7 No 1.

[28] Syifa, R. A., Adi, K., \& Widodo, C. E. (2016). ANALISIS TEKSTUR CITRA MIKROSKOPIS KANKER PARU MENGGUNAKAN METODE GRAY LEVEL CO-OCCURANCE MATRIX (GLCM) DAN TRANFORMASI WAVELET DENGAN KLASIFIKASI NAIVE BAYES. Youngster Physics Journal, Vol. 5, No. 4, Hal. 457-462.

[29] Vijayarani, D., \& Priyatharsini, S. (2015). Facial Feature Extraction Based On FPD and GLCM Algorithms. IJIRCCE, Vol. 3, Issue 3.

[30] Wahyuningsih, D., \& Patima, E. (2018, Februari). Penerapan Naive Bayes Untuk Penerimaan Beasiswa. Jurnal Telematika, Vol. 11 No. 1(ISSN : 1979 - 925X \& e-ISSN : 2442 - 4528), 135147.

[31] Zhong, W., Chen, J., Tian, B., \& Xie , Y. (2013). The Research of Color Sorting Algorithm Based on Gray Level Co - Occurrence Matrix. 